\title{
Crop production under different rainfall and management conditions in agroforestry parkland systems in Burkina Faso: observations and simulation with WaNuLCAS model
}

\author{
Y. N. Coulibaly $\cdot$ R. Mulia $\cdot$ J. Sanou \\ G. Zombré · J. Bayala $\cdot$ A. Kalinganire $\cdot$ \\ M. van Noordwijk
}

Received: 7 June 2013/ Accepted: 19 October 2013

(C) Springer Science+Business Media Dordrecht 2013

\begin{abstract}
Traditional agroforestry parkland systems in Burkina Faso are under threat due to human pressure and climate variability and change, requiring a better understanding for planning of adaptation. Field experiments were conducted in three climatic zones to assess Sorghum bicolor (L.) Moench (Sorghum) biomass, grain yield and harvest index in parklands under different rainfall pattern and compared to simulations of sorghum biomass and grain yield with the Water, Nutrient and Light Capture in Agroforestry Systems (WaNuLCAS) model for calibration and parametrisation. For planning adaptation,
\end{abstract}

Y. N. Coulibaly $\cdot$ J. Sanou

Département Productions Forestières, Institut de

1'Environnement et de Recherches Agricoles,

03 BP 7047 Ouagadougou 03, Burkina Faso

Y. N. Coulibaly · G. Zombré

Ecole doctorale sciences et Techniques, Université de Ouagadougou, 03 BP 7021 Ouagadougou 03,

Burkina Faso

R. Mulia · M. van Noordwijk

World Agroforestry Centre (ICRAF), Southeast Asia

Regional Programme JL, CIFOR, Situ Gede,

Sindang Barang, PO Box 161, Bogor 16115, Indonesia

J. Bayala $(\varangle) \cdot$ A. Kalinganire

World Agroforestry Centre (ICRAF), ICRAF-WCA/Sahel

Node, BP E5118 Bamako, Mali

e-mail: j.bayala@cgiar.org the model was then used to evaluate the effects of different management options under current and future climates on sorghum biomass and grain yield. Management options studied included tree densities, tree leaf pruning, mulching and changes in tree root patterns affecting hydraulic redistribution. The results revealed that sorghum biomass and grain yield was more negatively affected by Parkia biglobosa (Jacq.) Benth. (néré) compared to Vitellaria paradoxa C. F Gaertn (karité) and Adansonia digitata L. (baobab), the three main tree species of the agroforestry parkland system. Sorghum biomass and grain yield in different influence zones (sub-canopy, outside edge of canopy, open field) was affected by the amount of precipitation but also by tree canopy density, the latter depending itself on the ecological zone. The harvest index (grain as part of total biomass) was highest under the tree canopy and in the zone furthest from the tree, an effect that according to the model reflects relative absence of stress factors in the later part of the growing season. While simulating the effects of different management options under current and future climates still requires further empirical corroboration and model improvement, the options of tree canopy pruning to reduce shading while maintaining tree root functions probably is key to parkland adaptation to a changing climate.

Keywords Climate change $\cdot$ Hydraulic redistribution - Modeling $\cdot$ Roots $\cdot$ Scenarios . Tree-soil-crop interactions $\cdot$ WaNuLCAS 


\section{Introduction}

Parkland agroforestry systems are widely practiced in the drylands of the western part of Africa, often with Sorghum bicolor (L.) Moench (Sorghum) as major crop. In this cropping system with livestock as important component, trees are preserved in a naturally established, non-systematic pattern with relatively low tree density (Boffa 1999). In Burkina Faso tree density varies from farm to farm and was usually between 15 and 30 trees per hectare according to Kessler and Boni (1991). Farmers use different parts of the trees for marketed products, for domestic use and consumption, fodder, and for religious ceremonies (Bayala et al. 2002; Teklehaimanot 2004).

In these systems trees and crops may compete for light, water, and nutrients or have complementary needs (Sanchez 1995). Several research results showed a decrease of cereal crops yields under trees such as Parkia biglobosa (Jacq.) Benth. (néré) and Vitellaria paradoxa C. F. Gaertn (karité or shea tree) in parklands (Bayala et al. 2002; Boffa et al. 2000; Kessler 1992; Maiga 1987; Teklehaimanot 2004). Jonsson et al. (1999), however, found no difference between millet (Pennisetum glaucum (L.) R.Br.) yields under néré and karité tree canopies and in open areas during a good rainfall season. These contradictory results show that there is a need for a better understanding of the conditions which contribute to the improvement, depression, or variability of cereal production under canopies by conducting research in agroforestry parklands with different tree species and under different rainfall patterns. The extent of competition between tree roots and crops for soil nutrients and water in agroforestry parkland systems depends on the spatial distribution of tree and crop roots systems. Leaching of highly mobile nutrients is reduced when trees have a relatively dense root system beneath the crop root zone, through what is called a safety net function (Cadisch et al. 2004). Van Noordwijk and Cadisch (2002) showed such a safety net function for tree roots below a shallow-rooted maize (Zea mays L. Kernels) crop in situations with $20 \%$ or more of tree roots in the subsoil, using the Water, Nutrient and Light Capture in Agroforestry Systems (WaNuLCAS) model of tree-soil-crop interactions. Tree shade reduces both photosynthetically active radiation (PAR) and temperature which may both have an effect on the morphology, anatomy and physiology of crops grown beneath tree crowns. The tree leaf area index is key to PAR availability under tree crowns (Bellow and Nair 2003; Breman and Kessler 1995), but canopy shape matters too for the spatial pattern of crop performance. Zomboudré et al. (2005) showed that height and number of leaves of maize were lower under karité trees compared to open areas. They also noted a reduction of the number of leaves of maize by heavy shade under karité trees with a ball shaped crown compared to trees with a brush shaped crown. In this regard, it is important to understand how crops perform in distinct zones of interactions (sub-canopy, outside edge of canopy, open field) because of spatial patterns of tree leaf density and tree roots distribution which itself is influenced by rainfall distribution.

Parkland agroforestry systems have intensified over time and may have crossed thresholds of natural tree regeneration, while current climate variability and climate change may require further adjustment of tree species selection and tree management. The adaptation of these systems to these contexts is critical if these systems are to continue playing a major role in food security and household economy. Pruning of trees, increase of trees density through assisted tree regeneration, mulching are some key management practices recognized to improve crop productivity under climate variability and change (Bayala et al. 2012). The possibility of increasing solar irradiation and taking advantage of nutrient enrichment around trees is a strong argument in favour of pruning parkland trees (Bayala et al. 2002). Pruning néré trees resulted in higher sorghum yields relative to unpruned trees (Bayala et al. 2002; Bazié et al. 2012; Kessler 1992). Several studies reported that the practice of the assisted tree regeneration on parklands contribute to an increase of crop production, food security, tree density and species diversity (Adam et al. 2006; Barnes and Fagg 2003; Botoni and Reij 2009; Dramé and Berti 2008; Hadgu 2008; Kaboré and Reij 2004; Reij et al. 2009; Rhoades 1995). Other authors reported a negative effect of tree density increase on crop performance in agroforestry parklands which make farmers to reduce the density of the trees in their fields (Boffa 1999; Gijsbers et al. 1994; Kelly et al. 2004; Nikiéma 2005). As dry areas require a balancing act to optimize the ecological role of trees in maintaining favourable conditions for crop production we need more quantitative guidance on where to encourage farmers to maintain a higher density of trees 
(Bayala et al. 2006; Boffa 1999). It is then necessary to determine the biophysically-optimal tree densities in agroforestry parkland systems under different rainfall conditions. Poor soil fertility is a primary constraint limiting crop production in semi-arid West Africa, even outweighing moisture deficiency in the long run. The application of mulch in crop fields is recognized as another way of maintaining or enhancing soil fertility in these systems (Belsky et al. 1989). There is thus a need to understand how crop residues returning in the soil as mulch can affect crop performance under long-term crop cultivation in the agroforestry parkland systems.

The adaptation of the agroforestry parkland systems to climate change and variability needs a sufficient level of understanding of the system, its components, and their interactions. Beyond direct competition for water and nutrient, the trees provide shade and protection from supra-optimal temperatures (temperatures above the optimum) for the crop (Jonsson et al. 1999) as well as support the maintenance of soil organic matter through above- and belowground litter inputs. Under specific conditions (Bayala et al. 2008a) hydraulic equilibration of soil layers and zones connected by tree roots can bring subsoil water into the reach of crop roots and relieve water stress. This process was initially called hydraulic lift (Dawson 1993) and defined as a process of transferring water from wet subsoil to dry surface soil due to the presence of tree roots. This process depends on the water potential between the subsoil and the surface soil. The reverse process, transfers from wet surface layers to dry subsoil is possible (Burgess et al. 1998; Smith et al. 1998); hence the preference for the more neutral term of hydraulic redistribution (HR). There is a need to understand how this process of HR is affected by the depth of tree rooting system. Due to the complexity of the interactions in agroforestry systems, modeling has been thought to be a useful tool to help reaching the understanding of interactions in these systems faster and cheaper than a purely empirical approach could do (Bayala et al. 2008b; Kho 2000; Van Noordwijk and Lusiana 1999). Modeling helps reducing time, labor, and funds for establishing experiments to test a hypothesis about plant growth and performance.

The WaNuLCAS model (van Noordwijk et al. 2011) has been used for exploring tree-soil-crop interactions in the parkland systems of Burkina Faso (Bayala et al. 2008b). This model can simulate systems where sorghum is grown together with multipurpose trees such as baobab, néré and karité under different management options and climate scenarios. Further model validation is needed before model scenarios can be trusted to reflect the real choices farmers have.

The study was conducted at three sites located in different climatic zones of Burkina Faso to take into account the effect of the current climate on sorghum biomass, grain yield and harvest index in agroforestry parkland systems. After a validity test of the WaNuLCAS model against these data, the model was used to explore the effects of management scenarios that included longterm cropping with or without mulching and tree density with or without pruning for the three main tree species (baobab, néré and karité) on sorghum biomass and grain yield. Additionally, the effect of climate change scenarios on sorghum biomass were explored under changes in rainfall amount with a dynamic tree canopy (tree canopy is growing together with the sorghum) and fixed tree canopy (tree canopy is not growing and only sorghum growing) (van Noordwijk et al. 2011), and under tree with superficial and deeper root systems to test the HR function. The effect of changes in rainfall distribution patterns during the growing season on sorghum biomass has also been tested.

The overall aim of the field and simulation investigations was to come up with recommendations for improving agroforestry parkland management leading to its better adaptation to both the current climate variability and the future climate change. Specifically, four hypotheses were tested: (i) Sorghum performance (biomass, grain yield and harvest index) increases as precipitations increase, (ii) Néré trees with their dense canopy affects the performance (biomass, grain yield and harvest index) of sorghum more severely than baobab and karité trees, (iii) Sorghum performance (biomass, grain yield and harvest index) increases as the distance to the tree trunk increases, and (iv) Applying an appropriate management regime to the tree component can help for better adaptation of the parkland systems to climate change and variability.

\section{Materials and methods}

Site description

Field experiments were conducted at three different sites along an increasing rainfall gradient: Tougouri 
Table 1 Soil characteristics in the three study sites representing the northern (Tougouri), central (Nobéré) and southern (Sokouraba) parts of Burkina Faso in West Africa

\begin{tabular}{llll}
\hline Parameter & Tougouri & Nobere & Sokouraba \\
\hline \% Clay & 42.6 & 33.8 & 56.1 \\
\% Silt & 25.0 & 25.6 & 23.3 \\
\% Sand & 32.4 & 40.6 & 20.6 \\
CEC (meq/100 g) & 10.13 & 5.81 & 9.34 \\
Organic matter (\%) & 0.43 & 0.39 & 1.05 \\
N content (\%) & 0.03 & 0.02 & 0.07 \\
P content (P-Bray) (ppm) & 2.20 & 9.56 & 5.38 \\
pH & 5.92 & 6.43 & 5.71
\end{tabular}

The values are the average of top $50 \mathrm{~cm}$ soil layer

located at $13^{\circ} 18^{\prime} 59^{\prime \prime}$ latitude North and $-3^{\circ} 12^{\prime} 1^{\prime \prime}$ longitude West in the Sahelian zone (northern part); Nobéré located at $11^{\circ} 33^{\prime} 29^{\prime \prime}$ latitude North and $-1^{\circ} 12^{\prime} 16^{\prime \prime}$ longitude West in the Sudano-Sahelian savanna (central part) and Sokouraba located at $10^{\circ} 51^{\prime} 00^{\prime \prime}$ latitude North and $-5^{\circ} 11^{\prime} 00^{\prime \prime}$ longitude West in the Sudano-Guinean savanna (southern part). Soils at Tougouri were light clay while soils in Nobéré were sandy. The highest values for soil chemical properties were observed at Sokouraba, except for CEC and $\mathrm{P}$ (Table 1). Average rainfall (year 1980-2011) and temperature (year 2009-2011) were $557 \mathrm{~mm}$ and $26.6{ }^{\circ} \mathrm{C}$ in Tougouri, $859 \mathrm{~mm}$ and $25.7^{\circ} \mathrm{C}$ in Nobéré, and $1,061 \mathrm{~mm}$ and $25.1{ }^{\circ} \mathrm{C}$ in Sokouraba (DGM 2011). In the year of measurement, the rainfall totaled 620,775 and $927 \mathrm{~mm}$, respectively in Tougouri, Nobéré and Sokouraba.

\section{Experimental design}

The studied parkland systems consisted of an association of sorghum and three native tree species: baobab, néré and karité. Baobab was present with relatively dense stands only at Nobéré as mentioned by Kindt et al. (2008). Sorghum was cultivated in concentric zones under each tree species. The area around each of the sampled trees was split into three concentric tree influence zones and a control plot which were:

- Zone 1-from tree trunk to half of the crown radius of the tree;

- Zone 2-from half of the crown radius of the tree up to the edge of the crown;
- Zone 3-from the edge of the tree crown up to $3 \mathrm{~m}$ away; and

- Zone 4-a control plot for crop in monoculture for each sample tree which was an area of $4 \times 4 \mathrm{~m}$ situated at least $40 \mathrm{~m}$ away from the edge of the crown and unshaded by any of the surrounding trees at any time of the day throughout the cropping season (Bayala et al. 2002).

This design was replicated eight times for each tree species to give a total of $64[=8 \times(2 \times 4)]$ tree-byzone yield measurements in Sokouraba and Tougouri (two tree species), and 96 in Nobéré (three tree species).

Field observations and data collection for calibrating the model

Tree characteristics, sorghum biomass, grain yield, harvest index, phenology and management, both tree and sorghum root length densities and soil properties were measured in the three study sites and the data were used to calibrate WaNuLCAS model.

\section{Characteristics of trees}

Trees on farm were selected after discussions and with the agreement of the land owners. Trees were selected in such a way that they were distant enough to avoid overlap of shades of the sampled trees. The tree parameters measured included tree total height, tree canopy height, tree canopy diameter, stem diameter at breast height and tree biomass was later calculated. Tree total height was measured from the soil surface up to the limit of the crown height using a telescopic meter. Stem height was measured from the soil surface up to the beginning of the tree crown. Tree canopy height was then calculated as the difference between the total height and the stem height. Tree canopy diameter has been obtained by making an average of the values of diameter measured according to the directions north-south and west-east from the tree trunk to the edge of the tree crown using a measuring tape (Table 2).

The functional branch analysis (FBA) method was applied to determine tree biomass (van Noordwijk and Mulia 2002). The approach is based on the empirical allometric scaling equations $\left(\mathrm{Y}=\mathrm{aD}^{\mathrm{b}}\right)$ for tree biomass (Y) on the basis of stem diameter (D). The 
Table 2 Average dimensions of the sampled trees of Adansonia digitata L. (Baobab), Parkia biglobosa (Jacq.) Benth. (néré) and Vitellaria paradoxa C. F Gaertn (karité) in each of three study sites representing the northern (Tougouri), central (Nobéré), and southern (Sokouraba) parts of Burkina Faso in West Africa

\begin{tabular}{|c|c|c|c|c|c|}
\hline Site & Species & Tree height (m) & Canopy height (m) & Canopy diameter (m) & Stem diameter $(\mathrm{cm})$ \\
\hline Sokouraba & Karité & 9.14 & 5.4 & 10.32 & 33 \\
\hline Sokouraba & Néré & 9.92 & 5.0 & 10.71 & 47 \\
\hline Tougouri & Karité & 9.0 & 5.0 & 14.68 & 40 \\
\hline Tougouri & Néré & 11.0 & 9.0 & 14.45 & 43 \\
\hline Nobéré & Karité & 9.5 & 7.5 & 11.83 & 53 \\
\hline Nobéré & Néré & 11.0 & 9.0 & 17.14 & 69 \\
\hline Nobéré & Baobab & 15.5 & 10.0 & 16.52 & 188 \\
\hline
\end{tabular}

Baobab trees only exist in Nobéré site. Eight trees were sampled for each species in each site

intercepts $\mathrm{a}$ and $\mathrm{b}$ are generated by the FBA model. This equation is used to calculate the initial biomass of the different components of the trees to be integrated in the WaNuLCAS during the calibration. This equation also is integrated in the model to calculate the growth of the trees during the simulations. The FBA model provides a transparent scheme for deriving tree-specific scaling rules (especially, the $b$ parameter) on the basis of easily observable, non-destructive methods which consist in counting the number of branching points up to 100 on each sampled tree and to measure the diameter and length of each link. The three tree species phenology was assessed by following throughout one year the period of flowering, fructification and maturation of fruits for the three studied species.

\section{Sorghum biomass, yield, harvest index, phenology and management}

Sorghum biomass was measured in each of the influence zones associated to each tree species in each of the study sites. All the stems of sorghum were harvested at the collar, dried in sun for 1 month and weighed. For sorghum grain yield, all ears in each of the influences zones were harvested, dried, winnowed then weighed using a balance. The harvest index was measured by dividing the value of the grain yield by the total biomass value. The sorghum phenology was monitored during the cropping season by determining the period of flowering, fructification and maturation of grains. The management of the sorghum was also monitored by noting all the mineral and organic inputs applied to the crop for its growth.

\section{Sorghum and tree root length density}

For the measurement of sorghum and tree root length density, soil sampling was conducted randomly at two points in each of the concentric tree influence zones at $10 \mathrm{~cm}$ interval depth up to $50 \mathrm{~cm}$ near sorghum plants using an auger of $5 \mathrm{~cm}$ diameter. The two soil samples for the same depth were mixed to have a composite sample of $500 \mathrm{~cm}^{3}$. From this composite sample, the soil was washed using the Root Washer (Delta-T, UK) in a laboratory to separate roots from the soil. Roots were then classified in two categories: trees and sorghum. Only fine roots with diameter less than $2 \mathrm{~mm}$ were considered. The root length of trees and sorghum in centimeter were estimated using the method of Tennant (1975), which implies that roots are spread out on a grid of $1 \times 1 \mathrm{~cm}$ and the number of intersections of roots with the vertical and horizontal lines are counted. The following formula was used for the calculation of root length:

$\mathrm{L}=\pi \mathrm{ND} / 4$

with: $\mathrm{N}=$ number of intersections; $\mathrm{D}=$ width $(\mathrm{cm})$ of the grid and $\mathrm{L}=$ root length $(\mathrm{cm})$

When the samples were too small with less than 30 intersections for a grid of $1 \mathrm{~cm}$, direct measurements of the length were taken using a ruler. The root length density in $\mathrm{cm} \mathrm{cm}^{-3}$ was calculated by dividing the root length of each category of roots with the volume of soil used to extract the roots (Bayala et al. 2004).

\section{Soil properties}

Similar soil sampling procedures, as used for roots extraction, were used. The composite samples 
obtained were sieved and scanned using the near infrared method for the determination of the physical and chemical properties (Du and Zhou 2009; Shepherd and Walsh 2002). Wet chemistry analyses in the laboratory were also done on $10 \%$ of the soil samples and the results served as a reference to determine soils characteristics from the data provided by scanning the samples. Soil properties measured were phosphorus content ( $\mathrm{P}_{\mathrm{BRAY}}$ method), percentage of clay, percentages of silt, sand and organic carbon, $\mathrm{pH}$ and CEC.

\section{Model calibration and validation}

The WaNuLCAS model is composed of WaNuLCAS Excel linked to WaNuLCAS Stella. For the model calibration the data collected from the field were integrated in WaNuLCAS Excel file by answering to the appropriate questions as well as daily climatic data during the cropping season for each site. The parkland system studied is also defined by specifying the period of sorghum cultivation as well as the period of tree planting. In this study the system defined is that sorghum is growing with mature trees with no fertilizer application and no tree pruning. The initial leaf, twig and stem biomasses generated by WaNuLCAS Excel were then copied and pasted into WaNuLCAS Stella. In WaNuLCAS Stella, the widths of the 4 successive lateral zones as defined above were defined and were 4, 4, 2, and $2 \mathrm{~m}$ respectively. Sorghum was cultivated in all zones and a tree was in the first zone. The studied mature trees in the field displayed 5-9 $\mathrm{m}$ of canopy radius (Table 2), which means that for some species sorghum in the first two zones were under complete shading while those of the third zone were partially shaded (vertical or lateral shading). The fourth zone represents 'sorghum control plot' where we assume no shading from tree occurs at any time during the day, and no tree roots exist to influence belowground resource extraction and growth of the sorghum. It can also be considered as a 'pseudo zone' because with 25 trees $\mathrm{ha}^{-1}$ in the system, the distance between two trees would in a regular spacing be $20 \mathrm{~m}$ (i.e. that gives only $10 \mathrm{~m}$ total zone width according to the scheme applied in the WaNuLCAS model if the tree distribution was regular). The use of the pseudozone here is to make the model simulations simpler and faster (i.e. no separate simulation for sorghum control plot is required). We assumed the soils in the system were suitable for growth down to $2 \mathrm{~m}$ depth. The soils were divided into four horizontal layers with $0.1 \mathrm{~m} \quad(0-10 \mathrm{~cm}), \quad 0.2 \mathrm{~m} \quad(10-30 \mathrm{~cm}), \quad 0.7 \mathrm{~m}$ $(30-100 \mathrm{~cm})$, and $1 \mathrm{~m}$ thickness $(100-200 \mathrm{~cm})$ respectively from the soil surface. The soil characteristic of the third layer was estimated based on soil samples of the $0.3-0.5 \mathrm{~m}$ depth; and the characteristics of the fourth were assumed to be similar to those of the third layer. After the integration of the different inputs parameters into the WaNuLCAS Excel and Stella models, it was then used to describe plant-soilatmosphere interactions in the three observed sites and to simulate sorghum biomass and grain yield. The observed and simulated sorghum biomass and grain yield were then compared to evaluate the accuracy of the model prediction. The student t- statistics were used to test whether the slope of the observed vs. simulated values is significantly different from a unit value or not.

Model simulations and scenarios

To simulate model scenarios, parkland system with Nobéré climate (927 $\mathrm{mm}$ in the year 2011) and soil characteristics and néré tree species at density of 25 trees $\mathrm{ha}^{-1}$ was used as baseline conditions. The density of 25 trees $^{-1}$ was used as baseline density because it has been reported to be the maximum value of néré density in parkland systems in Burkina Faso (Hall et al. 1997; Ouédraogo 1995; Sina 2006). The first scenarios simulated were the effect of management options on sorghum biomass and yield under current climate. The management options tested under current climate was the effect of long-term (10 years) cropping without inorganic fertilizer and with sorghum residues returning to the soil as organic matter (mulching). Moreover the effect of reducing and increasing tree density $(9,16,25,36$, and 49 trees per hectare) in association with 20 and $50 \%$ of tree leaf pruning were tested. The second set of scenarios simulated were the effect of changes in rainfall regime in association with tree management as adaptation strategies to climate change on sorghum biomass. The rainfall regimes tested were the increase and decrease in the amount of rainfall as well as changes in rainfall pattern. The changes in rainfall pattern have been made by changing the variance of daily rainfall event compared to baseline using a rain simulator. Then rainfall distributions with different coefficients of 
variation were generated by a rainfall simulator that is part of the WaNuLCAS Excel model. Higher values of the coefficient of variation indicated a distribution with occasionally more extreme rainfall events in the rainy season. The associated tree management as adaptation strategies to climate change tested in simulating changes of rainfall regimes effect on sorghum biomass were tree canopy growing (dynamic) or not (fixed) with tree performing HR function with deeper and surface root system. In all scenarios except the simulation of the long-term cropping, the model was run for 1-year simulation.

\section{Statistical analysis}

For the field experiments the effects of tree species, site, zone and their interactions on sorghum biomass, grain yield and harvest index parameters were evaluated by multifactorial ANOVA using the general linear model (GLM), with least significance difference tests for multiple comparisons. Due to incomplete combination between site and tree species, only interaction between site and zone was considered.

\section{Results}

Field observations

The results indicated that there was significant difference in sorghum growth between sites, species, and zones as well as significant interactions between site and zone for sorghum biomass and grain yield (Table 3). The sorghum biomass and yield were higher at Sokouraba compared to the two other sites whereas the highest harvest index was obtained at Tougouri which is the driest site (Fig. 1a). Néré displayed more severe reduction in sorghum biomass and grain yield while the harvest index was not affected by tree species (Fig. 1b). Sorghum biomass and grain yield increased with increasing distance from the tree trunk to the open area with the largest harvest index values observed in zone 1 and zone 4 (Fig. 1c). Comparing zones across sites revealed higher sorghum biomass in zone 1 at Sokouraba whereas Sokouraba and Nobéré showed higher values in zones 2, 3 and 4 as opposed to Tougouri which had lower sorghum biomass in all the zones (Fig. 1d). Regardless of the zone, sorghum grain yield was higher at Sokouraba. A clear pattern of sorghum
Table 3 Probability values of the general linear model (GLM) procedure for the test of significance of observed site, adjacent tree species, (Adansonia digitata, Parkia biglobosa and Vitellaria paradoxa) and zone to sorghum growth for Tougouri, Nobéré and Sokouraba sites in Burkina Faso in West Africa

\begin{tabular}{llll}
\hline Source & \multicolumn{4}{l}{ GLM test $P$ value } \\
\cline { 2 - 4 } & Biomass & Grain yield & HI \\
\hline Site & $0.000^{* * *}$ & $0.000^{* * *}$ & $0.014^{*}$ \\
Tree $\times$ species & $0.001^{* *}$ & $0.001^{* *}$ & 0.100 \\
Zone & $0.001^{* *}$ & $0.001 * *$ & $0.001 * *$ \\
Zone $\times$ site & $0.003^{* *}$ & $0.003^{* *}$ & 0.135 \\
\hline$* P<0.05 * * P<0.01$ and $* * * P<0.001$ &
\end{tabular}

grain yield increasing with distance from the tree trunk was observed in Nobéré whereas the opposite was shown in Tougouri (Fig. 1e). A U-shaped pattern was observed for harvest index according to zones and sites (Fig. 1f), with the lowest harvest index in zone 2 or 3 .

\section{Model calibration and validation}

The dimensions of néré (Height $=9.92 \pm 0.36 \mathrm{~m}$; stem diameter $=47.67 \pm 2.91 \mathrm{~cm}$; Canopy height $=$ $7.67 \pm 1.33 \mathrm{~m}$; canopy diameter $=14.10 \pm 1.86 \mathrm{~m}$ ) and karité (Height $=9.14 \pm 0.15 \mathrm{~m}$; stem diameter $=42.00 \pm 5.86 \mathrm{~cm} ; \quad$ Canopy height $=5.97 \pm$ $0.78 \mathrm{~m}$; canopy diameter $=12.28 \pm 1.28 \mathrm{~m}$ ) trees were comparable (Table 2). The sampled trees of néré and karité were smaller in size in Sokouraba and Tougouri compared to those selected in Nobéré site. The morphology and phenology of studied species were different. Néré has a compound leaf whereas karité and baobab have a single leaf type and with apparent differences in specific leaf area and leaf density as well. Phenologically, néré starts flowering earlier than the two other tree species while karite is known to display a longer flowering period. Statistical analysis revealed no significant difference in tree root length densities $(P$ values $>0.05)$ despite differences in sizes of trees, tree species, sites, and zones. In turn, root density significantly decreased with soil depth regardless of the above mentioned factors. Soil physical and chemical properties measured were different for all the three studied sites, then for the simulation soil properties for each site have been integrated in the model (Table 1). No significant species -site interaction was observed and, we therefore used a common tree root distribution profile that represented the average root 

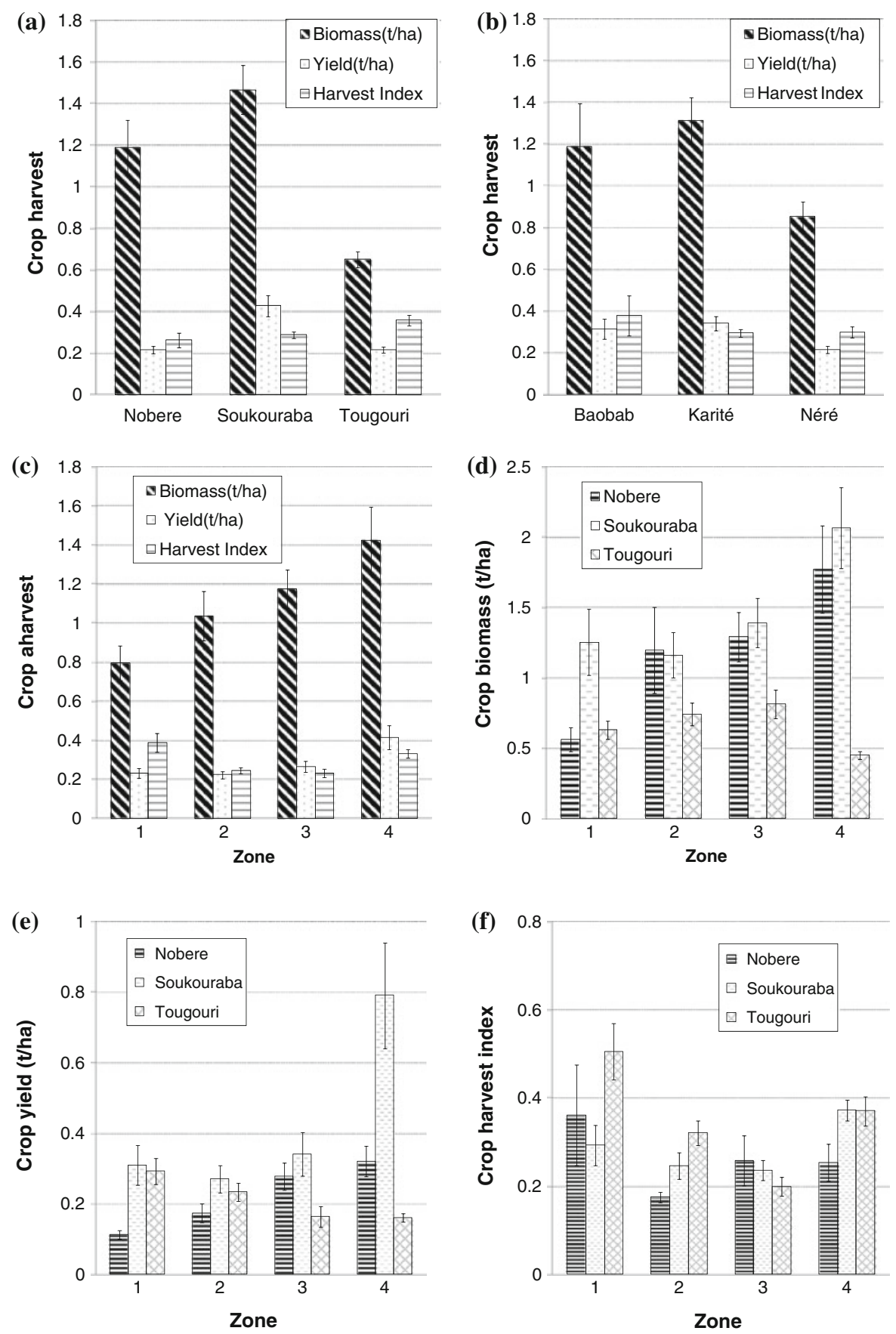

Fig. 1 Average crop biomass and grain yield in the three study sites and in different cultivated crop zones with different adjacent tree species (Adansonia digitata L. (Baobab), Parkia biglobosa (Jacq.) Benth. (néré) and Vitellaria paradoxa $\mathrm{C}$. $\mathrm{F}$ Gaertn (karité)). The harvest index is defined as the ratio between crop yield and biomass. The error bars are based on

one standard error of the average. Zone 1 from tree trunk to half of the crown radius of the tree; Zone 2 from half of the crown radius of the tree up to the edge of the crown; Zone 3 from the edge of the tree crown up to $3 \mathrm{~m}$ away; and Zone 4 a control plot for crop in monoculture for each sample tree which is an area of $4 \times 4 \mathrm{~m}$ situated at least $40 \mathrm{~m}$ away from the edge of the crown 
Fig. 2 Comparison between observed and simulated Sorghum bicolor (L.) Moench (sorghum) biomass (a) and grain yield (b) in Parkia biglobosa parkland systems, in the three study sites representing the northern (Tougouri), central (Nobéré), and southern (Sokouraba) parts of Burkina Faso in West Africa. The dashed diagonal lines represent 1:1 relationship between the observed and simulated values (a)

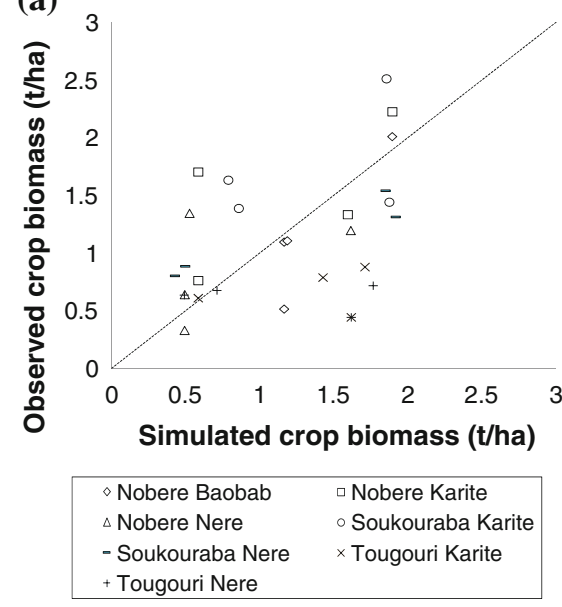

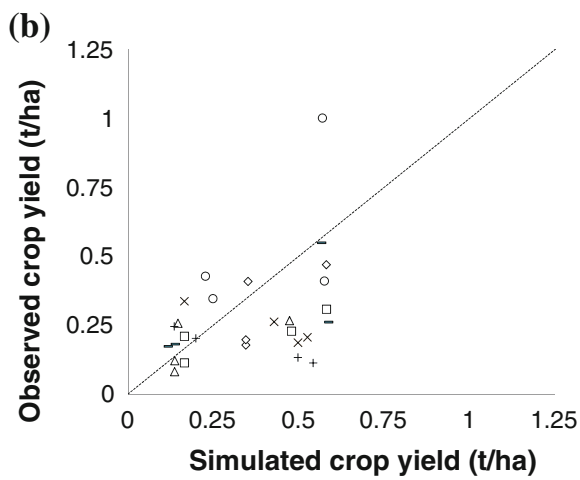

\begin{tabular}{|ll|}
\hline$\diamond$ Nobere Baobab & $\square$ Nobere Karite \\
$\triangle$ Nobere Nere & $\circ$ Soukouraba Karite \\
- Soukouraba Nere & $\times$ Tougouri Karite \\
+ Tougouri Nere & \\
\hline
\end{tabular}

length density for all species, all sites, all zones but different between profile layers. The estimated slope of linear relation between observed and simulated values was found to be within the range of $0.939 \pm 0.204$ for sorghum biomass and $0.902 \pm 0.176$ for grain yield with $\alpha$ equals 0.05 . This confirms that the model simulations can give fair estimations of the observed sorghum biomass and grain yield (Fig. 2a, b), although a substantial part of (may be soil related) variation remains unaccounted for.

Simulation of the effect of management options on sorghum biomass and grain yield under current climate

\section{The effect of long-term cropping and mulching}

Simulating continuous cropping without external inputs of late maturing sorghum variety (slow growth rate) showed stable biomass production both with and without returning sorghum residues as mulching to the same plot. A simulation with a medium maturing variety (maturing twice faster than the late maturing one) and a fast maturing (maturing four times faster than the late maturing one) showed decline in sorghum biomass and grain yield by the tenth cropping season in comparison with the first cropping season (Fig. 3a).

\section{The effect of tree density and tree pruning}

The simulations with 20 and $50 \%$ tree canopy pruning showed significant increases in the sorghum biomass and grain yield even when the tree density increased. An intriguing observation was that no decrease in sorghum biomass was observed with tree density above 25 trees ha $^{-1}$. In fact, the increase in tree density from 25 trees ha $^{-1}$ to 36 or 49 trees ha $^{-1}$ did not cause decrease in sorghum biomass (Fig. 3b).

Simulation of the effect of rainfall regime on sorghum biomass

The effect of rainfall amount on sorghum biomass with dynamic and fixed tree canopy

With dynamic tree canopy, sorghum showed higher biomass at Tougouri, the driest site, as a consequence of poorer growth of the canopy in this site resulting in lower leaf area index, less shade and less competition for light. In turn, wetter conditions favored faster growth and more severe shade in the two other sites. When no tree growth was simulated, rainfall gradient (represented by the sites) did not exert a significant impact on sorghum biomass which was experiencing the same level of shade in all sites (Fig. 4a).

Simulation of the effect of tree performing $H R$ with deeper and surface root system on sorghum biomass

Simulations across a rainfall gradient with and without inclusion of HR for tree and crop roots revealed that tree root distribution influences whether HR has a net positive or negative effect on sorghum growth. For a relatively shallow tree root system HR positively 


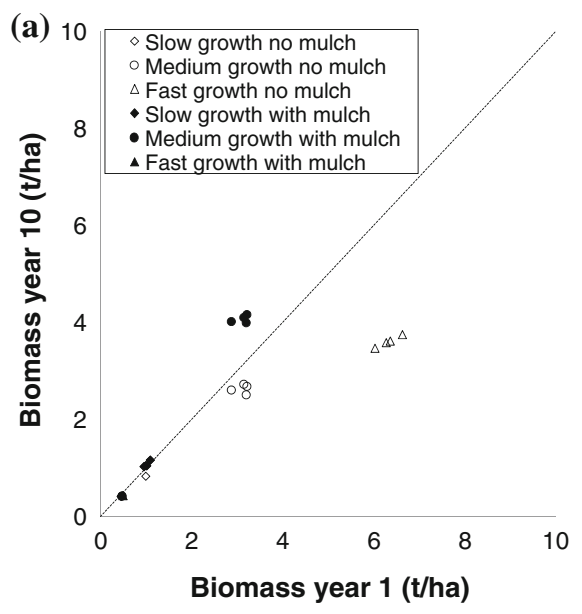

Fig. 3 Effects of management options on Sorghum bicolor (L.) Moench (sorghum) in Parkia biglobosa parklands in Burkina Faso in West Africa: a effect of long-term cropping on biomass with three simulated Sorghum bicolor (L.) Moench (sorghum)

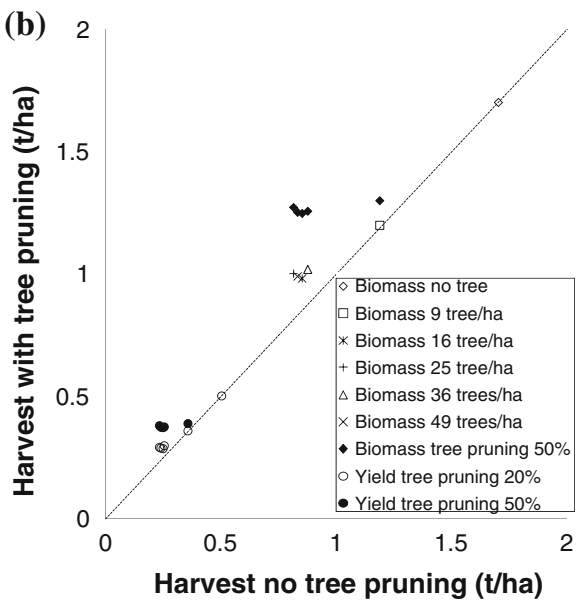

growth rates and an option of with or without returned sorghum mulching to the plot; $\mathbf{b}$ effect of increasing tree density in the parkland system with an option of tree canopy pruning (20\% or $50 \%$ ) or without pruning
Fig. 4 Effects of management options on Sorghum bicolor (L.) Moench (sorghum) in Parkia biglobosa parklands in Burkina Faso in West Africa: a effect of rainfall amounts on Sorghum bicolor (L.) Moench (sorghum) biomass under different tree canopy types (dynamic vs. fixed in dimension); $\mathbf{b}$ effect of simulating hydraulic lift (HL) function by tree root system on sorghum biomass, c effect of simulating hydraulic lift (HL) function by tree root system on sorghum biomass with changes in the depth of adjacent trees root system and $\mathbf{d}$ effect of rainfall patterns on sorghum growth in Burkina Faso in West Africa
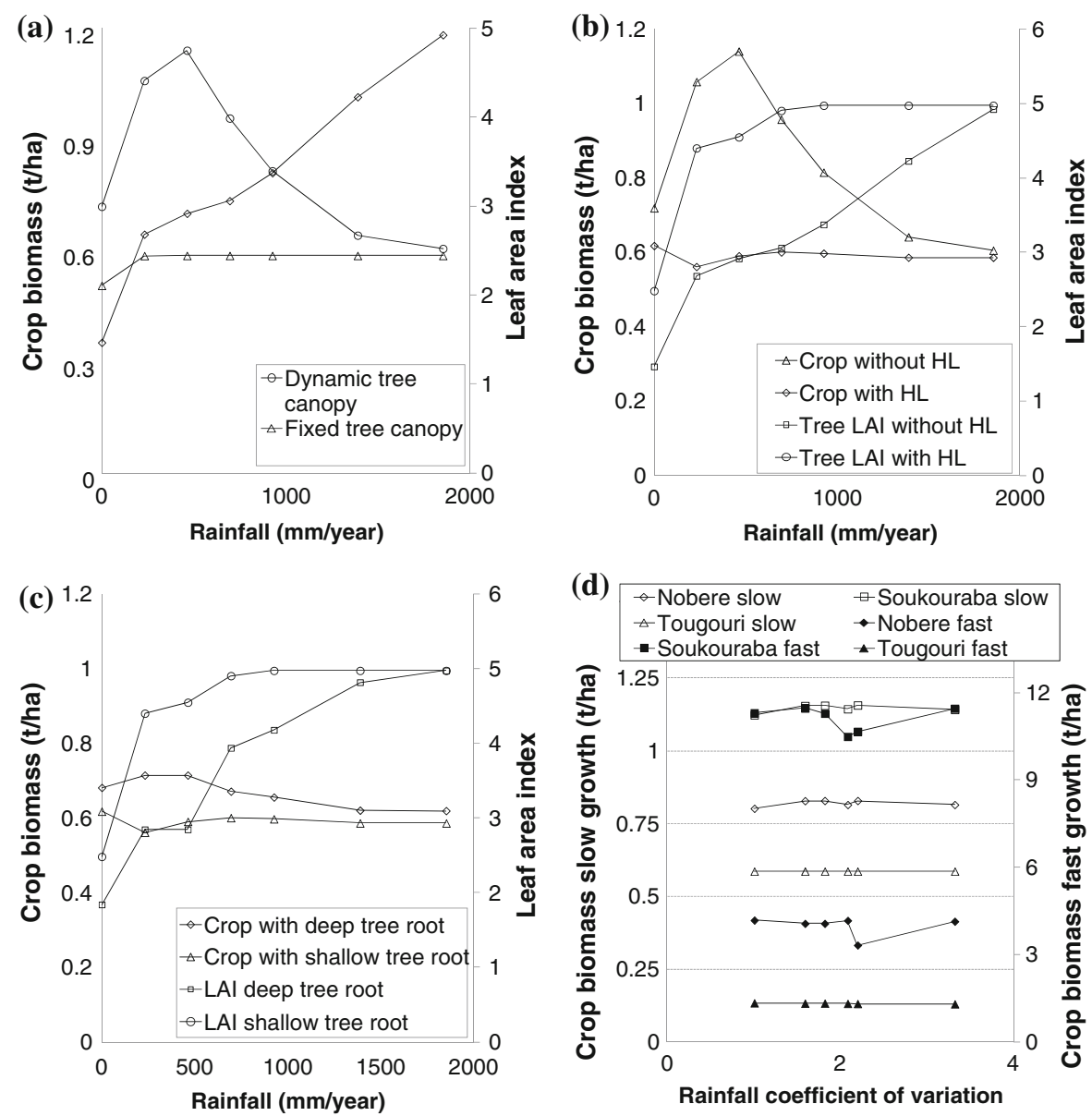
influenced tree leaf area index (Fig. 4b), but negatively affected the crop. For trees with relatively deep root systems, HR increased sorghum biomass (Fig. 4c).

\section{Simulation of the effect of rainfall pattern on sorghum biomass}

As shown in Fig. 4d, the changes in rainfall pattern did not have a strong effect on sorghum biomass especially when the growth rate is relatively slow (late maturing variety). This happened at the three sites despite the differences in soil texture and organic matter content between the sites (Fig. 4d).

\section{Discussion}

Field observations

Sorghum biomass and grain yield were higher at Sokouraba, the wettest site, compared to the two other sites while higher values of the harvest index were obtained at Tougouri, the driest site. This finding supports the hypothesis of better sorghum performance with higher rainfall. However sorghum performance cannot be solely explained by rainfall amount as other factors like soil fertility, rainfall distribution, crop variety and farmer's management may play a role. For instance it is well known that soils from the northern and central parts of the country have long been exposed to erosion and to continuous cropping without external inputs. In turn, the pressure on land is low in the south where farmers are still able to fallow their lands, to apply some inputs to some crops like cotton and maize. Sorghum coming after these crops in the rotation may benefit from the inputs leftover. Higher grain production relative to the total biomass (harvest index) at Tougouri could be due to the more assimilates allocation for grains development. In fact when water becomes a limiting factor, some varieties of sorghum are able to preferentially allocate assimilates to grains at the expense of the biomass as reported by Wenzel et al. (2000). This result is also in agreement with that of Bunce (1990) who showed a reduction of dry matter in soybean due to the production of abscissic acid under drought conditions which reduced leaves expansion and enhanced the export rates of photosynthates from the leaves to the reproductive organs. These processes of assimilates allocation between the reproductive and vegetative compartments of a plant seem to be under the influence of environmental conditions.

Néré parklands exerted more severe negative impact on sorghum performance both for biomass and grain yield confirming our working hypothesis on differential species effect. This finding agrees with those of previous studies (Bayala et al. 2002; Bazié et al. 2012; Jonsson et al. 1999; Kater et al. 1992; Kessler 1992; Sanou et al. 2012) which have shown that néré displays more shade associated with more light reduction. This species was found to reduce light by $62-80 \%$ (Bayala et al. 2002; Jonsson et al. 1999; Kessler 1992) compared to $40-65 \%$ by baobab (Belsky et al. 1989; Sanou et al. 2012), and $53 \%$ by karité (Bayala et al. 2002). Indeed, light has already been reported to be the most limiting factor influencing the development of cereal crop in agroforestry parkland systems by previous authors (Bayala et al. 2008b; Kater et al. 1992; Kessler 1992; Sanou et al. 2012). To this factor can be added others with more limited effects like water and nutrients competition (Bayala et al. 2008b), and canopy rainfall interception (Ong et al. 1996).

Sorghum biomass and grain yield of all sites lumped together and for Nobéré site increased with distance from tree trunk (Fig. 1c, d) whereas lower values of these two variables were recorded under the tree compared to the open area without a clear pattern elsewhere (Fig. 1d). In turn, higher biomass and yield were observed under the tree in Tougouri site (Fig. 1d). The result of better performance of cereals with distance to tree trunk is in accordance with the findings of Bayala et al. (2002), Boffa et al. (2000) and Kessler (1992). Sanou et al. (2012) showed that light reduction under tree crown decreases as soon as one moves away from the trunk and that may be the possible cause of the reduction in cereal performance under tree as observed in Sokouraba and Nobéré. When environmental conditions are dry, the presence of tree is more beneficial and favors a better performance of sorghum under the tree canopy as illustrated by the case of Tougouri. This corroborates the results of a meta-analysis of cereal responses to parklands that showed yield increased as compared to the control when annual average rainfall was less than $800 \mathrm{~mm}$ (Bayala et al. 2012). This shows that the effect of shade can, in some circumstances, be compensated for 
by better microclimatic conditions including but not limited to higher soil fertility, higher soil water content, lower temperature (Bayala et al. 2002; Jonsson et al. 1999).

Model calibration and validation

The results of the estimated slope of linear relation without intercept between observed and simulated values were within accepted ranges, confirming that the WaNuLCAS model can be used for simulations in the present study. Indeed, the Nash and Sutcliffe (1970) model efficiency coefficient (sum of squares of measured minus model, divided by sum of squares of measured minus mean) was calculated for the measured versus modelled biomass and yield data. A value of -0.099 was found for crop biomass (implying that the measured mean is slightly better than the model in accounting for the data) and a value of 0.207 for grain yield. The maximum value this coefficient can reach is 1.0 , so the model has scope for improvement, but accounts for $20 \%$ of the observed variation. The model had already been parameterized and validated for néré and karité by Bayala et al. (2008b). The current model, however, appeared to overestimate the crop performance with better estimates for biomass compared to harvestable grain yield.

Simulation of the effect of management options on sorghum biomass and grain yield under current climate

\section{The effect of long-term cropping and mulching}

With a slow growing (late maturing) sorghum variety we found no long-term decline in production, which may be due to the lower demand on growth resources of such crop variety. As it depletes soil nutrients slower it allows the recycling process through parkland trees to be fast enough to support long cropping phase without external inputs even under total removal of the sorghum residues. Indeed the woody component of the parklands has been reported to have larger contribution to soil carbon pools through its litter decomposition and its fine roots decay (Bayala et al. 2006; Lufafa et al. 2008). As opposed to a slow growing variety, medium and early maturing varieties might be extracting growth resources faster to a pace that recycling of tree litter and root could no longer sustain the system leading to a decrease in crop biomass by the tenth cropping season even when keeping sorghum residues as mulch. This highlights the need to supply inorganic or organic fertilizers to fast growing varieties under parklands especially of néré.

\section{The effect of tree density and tree pruning}

Simulating management options revealed an improvement in sorghum production on applying pruning at all tree densities. This finding supports the argument of light being the most limiting factor for cereals in parklands (Bayala et al. 2008b). Therefore, it can be recommended to increase the density of néré in parklands provided crown pruning is tactically applied to reduce shade during the cropping season. Such approach has several advantages of diversifying the production and maintaining the provision of tree ecosystem services (provisioning, supporting, and regulating) which are key for the long-term sustainability and offer adaptation possibilities to climate change.

Simulation of the effect of rainfall regime on sorghum biomass

\section{The effect of rainfall amount on sorghum growth with dynamic and fixed tree canopy}

The simulations of the effect of reducing or increasing the amount of the precipitations on sorghum biomass under fixed and dynamic tree canopy conditions showed that changes in rainfall amount affect sorghum biomass if the tree canopy is dynamic. Indeed, increasing rainfall is associated with increasing canopy that will display severe shade. Thus lower rainfall was found to be associated with less shade and better cereal performance through better access to light and better utilization of the island of high fertility associated with the presence of trees (Bayala et al. 2002, 2006; Buresh and Tian 1998). That might explain why farmers of the northern part of Burkina Faso, where Tougouri is located, have been very active since 1980' in rehabilitating degraded lands which translated into an increased tree diversity and density. With a tree density of about 126 trees ha ${ }^{-1}$ in such dry environments, cereal production increase by an average of at least $400 \mathrm{~kg} \mathrm{ha}^{-1}$ could be obtained by farmers 
(Reij et al. 2009). In such circumstances, the integration of trees into annual food crop systems can play an important role in adapting the agricultural systems to the droughts as a manifestation of future climate change. If the tree canopy is fixed, tree shade effect is predominant compared to the effect of changes in rainfall amount which practically does not affect sorghum biomass. Then the adaptation of the parkland systems to climate change that translates into higher rainfall should focus on tree crown pruning as an option to be explored to reduce the shade effect.

\section{Simulation of the effect of HR with dynamic canopy, deeper and surface tree root system on sorghum biomass}

Simulated sorghum biomass was reduced with a dynamic tree canopy and root system that performs hydraulic function. This is due to the fact that when HR occurs, the trees grow faster and develop larger crowns and cause more severe shade (Bayala et al. 2008a). Simulations across a rainfall gradient with and without inclusion of HR for tree and crop roots revealed that crop growth was inferior when tree root systems performed HR function with shallow roots. Shallow tree roots give them access to the richer soil layers and that lead to better growth for the tree. Although the crop root system can benefit from the water transported to topsoil by the tree root system, the faster growth of trees means more shading and suppression of crop growth. Indeed, under dry soil conditions, trees that performed HR function developed the highest leaf area index. But when the root system is located in deeper horizons, the trees cannot exploit the high fertility in the upper soil layers and therefore grow slowly and display less severe shade (van Noordwijk et al. 2012). It can be recommended to pay specific attention to species root architecture when they are being promoted to reclaim degraded lands. Tree species which perform this hydraulic function and have deep rooting system are most recommendable for such harsh environment.

\section{Simulation of the effect of rainfall pattern on sorghum biomass}

Variation of rainfall within the growing season can have little effect on crop growth as long as the buffering of soil moisture is not exceeded. The presence of trees can modify the water balance through interception and evapo-transpiration (Breman and Kessler 1995; Ong et al. 1996; Ong and Swallow 2004) as well as infiltration and ground water recharge (Ilstedt et al. 2007), enhancing buffering.

The manifestation of climate change for the Sahel region and particularly for Burkina Faso is expected to be an increase in temperature and a decrease or increase in rainfall amount according to the zones of the country (MECV 2006). There will also be an increase of extreme events like droughts and floods. Based on the results from the above simulations, it can be recommended to promote tree pruning to cope with the increase of rainfall amount and this can be associated with the long cycle sorghum varieties. In turn, trees with deeper root system should be promoted in drought prone areas.

\section{Conclusion}

In agroforestry parkland systems more water does not in all cases lead to a better sorghum grain production. Indeed the sorghum harvest index of the drier site of the present study was higher than that at the wetter sites. Sorghum performance, with its $\mathrm{C}_{4}$ photosynthetic pathway, is affected by the intense shading under néré rather than baobab and karité. Results of the present study also revealed that lower sorghum performance was observed under trees in wet sites (Sokouraba and Nobéré) whereas sorghum biomass and grain yield were higher under trees than in the open area in the driest site (Tougouri).

The WaNuLCAS model has been successfully calibrated for baobab, néré and karité parklands with sorghum crop. It could be used as a tool for planning management options for the sustainability of the system under several scenarios but also to formulate and test in the field research hypothesis. Scenarios of management options of the agroforestry system under current climate and future climate change have been tested with the WaNuLCAS model. Under the current climate conditions, increasing the tree density does not negatively affect sorghum growth if crown pruning is applied. Then it could be recommended to farmers to increase tree density on their farms and associated to that tactical tree crown pruning operations at the beginning of the rainy season to improve cereal production. Sorghum with slow growth rate could be 
cultivated on a long-term basis in agroforestry parklands without providing any organic or inorganic fertilizers and the sorghum performance will remain stable as opposed to fast growing sorghum varieties. Applying pruning will also be useful when flooding occurs as a consequence of changing climate as this operation will reduce shade in situation where tree growth is accelerated by the availability of water. Agroforestry practices using tree species with dynamic canopy and performing hydraulic function with deep root system is also recommended as an option to cope with the occurrence of extreme events like flooding and also drought.

An important limitation of this research is the fact we have worked on tree individuals of unknown age and unknown management history. Such information would have helped better desegregate the contributions of other factors beyond the ones studied. Longer term monitoring is also required if we have to come up with long-term patterns and trends in link with climate variability and change. Other aspects of parkland production than only biomass and grain yield need to be considered to be able to present a full picture of this very important farming system in the Sahel.

Acknowledgments This study was funded by the project Adaptation of Land Use to Climate Change in Sub Saharan Africa (ALUCCSA). We thank the farmers in Noberé, Sokouraba and Tougouri for their permission to perform the field experiment, and their participation. We also thank anonymous reviewers for comments on the manuscript.

\section{References}

Adam T, Abdoulaye T, Larwanou M, Yamba B, Reij C, Tappan G (2006) Plus de gens, plus d'arbres: La transformation des systèmes de production au Niger et les impacts des investissements dans la gestion des ressources naturelles. Rapport de Synthèse Etude Sahel Niger. Comité Permanent Inter-Etats de Lutte contre la Sécheresse dans le Sahel and Université de Niamey, Niamey

Barnes RD, Fagg CW (2003) Faidherbia albida: Monograph and Annotated Bibliography. Tropical Forestry papers No 41. Oxford Forestry Institute, Oxford

Bayala J, Teklehaimanot Z, Ouédraogo SJ (2002) Millet production under pruned tree crowns in a parkland system in Burkina Faso. Agrofor Syst 54:203-214

Bayala J, Teklehaimanot Z, Ouedraogo SJ (2004) Fine root distribution of pruned trees and associated crops in a parkland system in Burkina Faso. Agrofor Syst 60:13-26

Bayala J, Balesdent J, Marol C, Zapata F, Teklehaimanot Z, Ouedraogo SJ (2006) Relative contribution of trees and crops to soil carbon content in a parkland system in Burkina
Faso using variations in natural ${ }^{13} \mathrm{C}$ abundance. Nutr $\mathrm{Cycl}$ Agroecosys 76:193-201

Bayala J, Heng LK, van Noordwijk M, Ouedraogo SJ (2008a) Hydraulic Redistribution study in two native tree species of agroforestry parklands of West African dry savanna. Acta Oecologia 34:370-378

Bayala J, van Noordwijk M, Lusiana B, Kasanah N, Teklehaimanot Z, Ouedraogo SJ (2008b) Separating the tree-soilcrop interactions in agroforestry parkland systems in Saponé (Burkina Faso) using WaNuLCAS. Adv Agrofor 4:296-308

Bayala J, Sileshi GW, Coe R, Kalinganire A, Tchoundjeu Z, Sinclair F, Garrity D (2012) Cereal yield response to conservation agriculture practices in drylands of West Africa: a quantitative synthesis. J Arid Environ 78:13-25

Bazié HR, Bayala J, Zombré G, Sanou J, Ilstedt U (2012) Separating competition-related factors limiting crop performance in an agroforestry parkland system in Burkina Faso. Agrofor Syst 84:377-388

Bellow JG, Nair PK (2003) Comparing common methods for assessing understory light availability in shaded-perennial agroforestry systems. Agro For Meteorol 114:197-211

Belsky AJ, Amundson RG, Duxbury JM, Riha SJ, Ali AR, Mwonga SM (1989) The effects of trees on their physical, chemical, and biological environments in a semi-arid savanna in Kenya. J Appl Ecol 26:1005-1024

Boffa JM (1999) Agroforestry parklands in sub-Saharan Africa. FAO Conservation Guide 34, Rome

Boffa JM, Taonda SJ, Dickey JB, Knudson DM (2000) Fieldscale influence of karité (Vitellaria paradoxa) on sorghum production in the Sudan zone of Burkina Faso. Agrofor Syst 49:153-175

Botoni E, Reij C (2009) La transformation silencieuse de l'environnement et des systèmes de production au Sahel: L'impact des investissements publics et privés dans la gestion des ressources naturelles. Amsterdam, the Netherlands: Comité Permanent Inter-etats de Lutte Contre la Secheresse dans le Sahel (CILSS) and Vrije University Amsterdam

Breman H, Kessler JJ (1995) Woody plants in agro-ecosystems of semi-arid regions, with an emphasis on the Sahelian countries. Springer Verlag, Berlin

Bunce JA (1990) Abscisic acid mimics effects of dehydration on area expansion and photosynthetic partitioning in young soybean leaves. Plant Cell Environ 13(295):298

Buresh RJ, Tian G (1998) Soil improvement by trees in subSaharan Africa. Agrofor Syst 38:51-76

Burgess SSO, Adams MA, Turner NC, Ong CK (1998) Redistribution of soil water by tree root systems. Oecologia 115:306-311

Cadisch G, Rowe E, Suprayogo D, van Noordwijk M (2004) Safety-nets and filter functions of tropical agroforestry systems. In: Hatch DJ et al (eds) Controlling nitrogen flows and losses. Wageningen Academic Publishers, Wageningen, pp 406-414

Dawson TE (1993) Hydraulic lift and water use by plants: implications for water balance, performance and plant plant interactions. Oecologia 95:565-574

Direction Générale de la Météorologie (DGM) du Burkina Faso (2011) Base de données de climatiques du Burkina Faso, Ouagadougou, Burkina Faso 
Dramé YA, Berti F (2008) les enjeux socio-économiques autour de l'agroforesterie villageoise à Aguié (Niger). Tropicultura 26:141-149

Du C, Zhou J (2009) Evaluation of soil fertility using infrared spectroscopy: a review. Environ Chem Lett 7:97-113

Gijsbers HJ, Kessler JJ, Knevel MK (1994) Dynamics and natural regeneration of woody species in farmed parklands in the Sahel region (Province of Passoré, Burkina Faso). For Ecol Manag 64:1-12

Hadgu KM (2008) Temporal and spatial changes in land use patterns and biodiversity in relation to farm productivity at multiple scales in Tigray, Ethiopia. PhD dissertation, Wageningen University, The Netherlands

Hall JB, Tomlinson HF, Oni PI, Buchy M, Aebischer DP (1997) Parkia biglobosa: a monograph. University of Wales, Bangor

Ilstedt U, Malmer A, Verbeeten E, Murdiyarso D (2007) The effect of afforestation on water infiltration in the tropics: a systematic review and meta-analysis. For Ecol Manag 251:45-51

Jonsson K, Ong CK, Odongo JC (1999) Influence of scattered néré and karité trees on microclimate, soil fertility and millet yield in Burkina Faso. Exp Agric 35:39-53

Kaboré D, Reij C (2004) The emergence and spreading of an improved traditional soil and water conservation practice in Burkina Faso. Environment and production technology division working paper no. 114. International Food Policy Research Institute, Washington, DC

Kater LJ, Kante S, Budelman A (1992) Karité (Vitellaria paradoxa) and néré (Parkia biglobosa) associated with crops in South Mali. Agrofor Syst 18:89-105

Kelly BA, Bouvet JM, Picard N (2004) Size classes and spatial pattern of Vitellaria paradoxa in relation to farmers'practices in Mali. Agrofor Syst 60:3-11

Kessler JJ (1992) The influence of Karité (Vitellaria paradoxa) and Néré (Parkia biglobosa) trees on sorghum production in Burkina Faso. Agrofor Syst 17:97-118

Kessler JJ, Boni J (1991) L'agroforesterie au Burkina Faso. Bilan et analyse. Resource Management Papers 1. Université Agronomique Wageningen, Les Pays Bas

Kho RM (2000) A general tree-environment-crop interaction equation for predictive understanding of agroforestry systems. Agric Ecosys Environ 80:87-100

Kindt R, Kalinganire A, Larwanou M, Belem M, Dakouo JM, Bayala J, Kaire M (2008) Species accumulation within land use and tree diameter categories in Burkina Faso, Mali, Niger and Senegal. Biodivers Conserv 17:18831905

Lufafa A, Bolte J, Wright D, Khouma M, Diedhiou I, Dick RP, Kizito F, Dossa E, Noller JS (2008) Regional carbon stocks and dynamics in native woody shrub communities of Senegal's peanut basin. Agric Ecosys Environ 128:1-11

Maiga A (1987) L'arbre dans les systèmes agroforestiers traditionnels dans la province de Bazega. Influence du karité, du néré et de l'Acacia albida sur le sorgho et le mil. Mémoire Institut de développement rural (IDR). IRBET/ CNRST, Ouagadougou, Burkina Faso

Ministère de l'Environnement et du Cadre de Vie (MECV) (2006) Evaluation de la vulnérabilité et des capacités d'adaptation aux changements climatiques du Burkina Faso. Rapport provisoire, Burkina Faso
Nash JE, Sutcliffe JV (1970) River flow forecasting through conceptual models part I-A discussion of principles. J Hydrol 10(3):282-290

Nikiéma A (2005) Agroforestry Parkland Species Diversity: Uses and Management in Semi-Arid West Africa (Burkina Faso). PhD thesis Wageningen University, Wageningen, The Netherlands

Ong CK, Swallow BM (2004) Water productivity in forestry and agroforestry. In: Kijne W, Barker R, Molden D (eds) Water productivity in agriculture: limits and opportunities for improvement. CAB International, Oxon, pp 217-228

Ong CK, Black CR, Marshall FM, Corlett J (1996) Principles of resource capture and utilization of light and water. In: Ong CK, Huxley P (eds) Tree-crop interactions. A physiological approach, Wallingford, pp 73-158

Ouédraogo AS (1995) Parkia biglobosa (Leguminosae) en Afrique de l'Ouest: Biosystématique et Amélioration. $\mathrm{PhD}$ thesis. Institute for Forestry and Nature Research IBNDLO, Wageningen, The Netherlands

Reij C, Tappan G, Smale M (2009) Agroenvironmental Transformation in the Sahel: Another kind of "green revolution”. IFPRI Discussion paper 00914. International Food Policy Research Institute, Washington DC

Rhoades C (1995) Seasonal pattern of nitrogen mineralization and soil moisture beneath Faidherbia albida (syn Acacia albida) in central Malawi. Agrofor Syst 29:133-145

Sanchez PA (1995) Science in agroforestry. Agrofor Syst 30:1-55

Sanou J, Bayala J, Teklehaimanot Z, Bazie P (2012) Effect of shading by baobab (Adansonia digitata) and néré (Parkia biglobosa) on yields of millet (Pennisetum glaucum) and taro (Colocasia esculenta) in parkland systems in Burkina Faso, West Africa. Agrofor Syst 85:431-441

Shepherd KD, Walsh MG (2002) Development of reflectance spectral libraries for characterization of soil properties. Soil Sci Soc Am J 66:988-998

Sina S (2006) Reproduction et Diversité Génétique chez Parkia biglobosa (Jacq.) G. Don. Dissertation, Wageningen University, The Netherlands

Smith DM, Jackson NA, Roberts JM, Ong CK (1998) Reverse flow in tree roots and downward siphoning of water by Grevillea robusta. Funct Ecol 13:256-264

Teklehaimanot Z (2004) Exploiting the potential of indigenous agroforestry trees: Parkia biglobosa and Vitellaria paradoxa in sub-Saharan Africa. Agrofor Syst 61:207-220

Tennant D (1975) A test of a modified line intersect method of estimating root length. J Appl Ecol 63:995-1001

van Noordwijk M, Cadisch G (2002) Access and excess problems in plant nutrition. Plant Soil 247:25-40

van Noordwijk M, Lusiana B (1999) WaNuLCAS a model of water, nutrient and light capture in agroforestry systems. Agrofor Syst 43:217-242

van Noordwijk M, Mulia R (2002) Functional branch analysis as tool for fractal scaling above-and belowground trees for their additive and non-additive properties. Ecol Model 149:41-51

van Noordwijk M, Lusiana B, Khasanah N, Mulia R (2011) WaNuLCAS Version 4.0, Background on a model of water, nutrient and light capture in agroforestry systems. International Center for Research in Agroforestry (ICRAF), Bogor, Indonesia 
van Noordwijk M, Mulia R, Bayala J (2012) Buffering soil water supply to crops by hydraulic equilibration in conservation agriculture with deep-rooted trees: application of a process-based tree-soil-crop simulation model to parkland agroforestry in Burkina Faso. In: Hauswirt D, Sen PT et al. (eds.) Conservation Agriculture and Sustainable Upland Livelihoods Innovations for, with and by Farmers to Adapt to Local and Global Changes, proceedings of the 3rd International Conference on Conservation Agriculture in Southeast Asia, Hanoi 2012, pp 176-179
Wenzel W, Ayisi K, Donaldson G (2000) Importance of harvest index in drought resistance of sorghum. J Appl Bot 74(5-6):203-205

Zomboudré G, Zombré G, Zombré G, Ouedraogo M, Guinko S, Roy Macauley H (2005) Réponse physiologique et productivité des cultures dans un système agroforestier traditionnel : cas du maïs (Zea mays L.) associé au karité (Vitellaria paradoxa Gaertn.) dans la zone est du Burkina Faso. BASE 9(1):75-85 